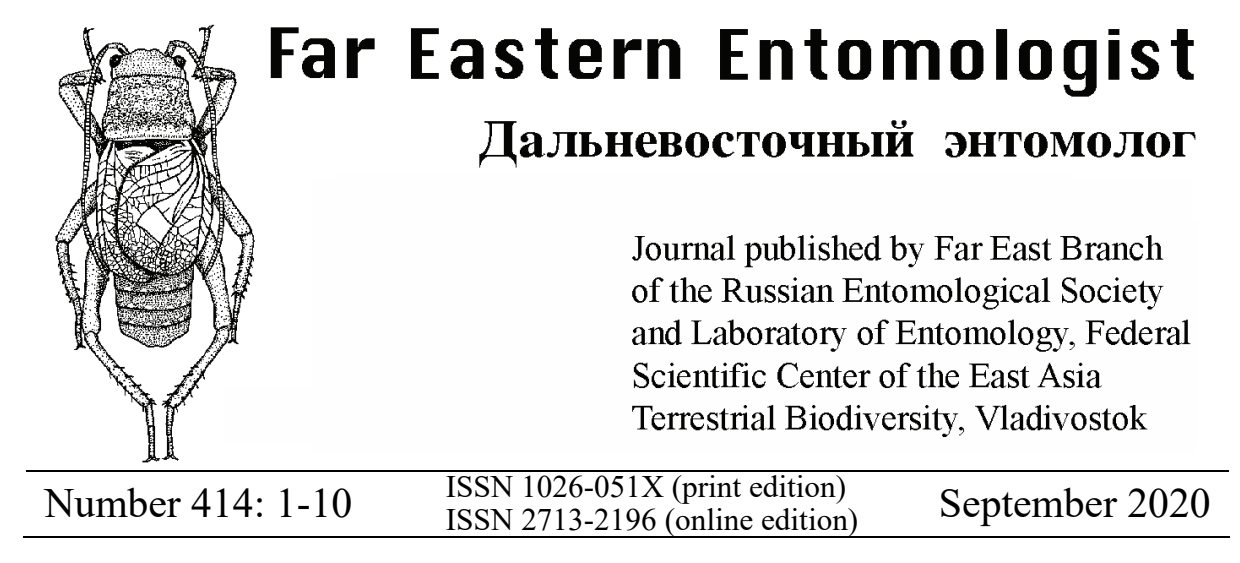

https://doi.org/10.25221/fee.414.1

http://zoobank.org/References/208C3B4F-4E12-4D71-9540-2AB96D143EFE

\title{
CHIRONOMID COMMUNITY (DIPTERA: CHIRONOMIDAE) OF TEMPORARY STREAM OF SOUTHERN PRIMORYE, RUSSIAN FAR EAST
}

\author{
T. M. Tiunova*, E. A. Makarchenko \\ Federal Scientific Center of the East Asia Terrestrial Biodiversity, Far East Branch \\ of the Russian Academy of Sciences, Vladivostok, 690022, Russia. \\ *Corresponding author, E-mail: tiunova@biosoil.ru
}

Summary. During the April to June and October 2013, chironomids fauna of temporary stream of Primorye Territory has been studied from the water and dry periods. A total of 26 taxa were identified during the study, comprising the subfamilies Diamesinae, Orthocladiinae, Chironominae and Tanypodinae. This temporary stream is a type locality for five species: Lappodiamesa omelkoi Makarchenko et Makarchenko, 2013, Hydrobaenus distinctus Makarchenko et Makarchenko, 2006, H. majus Makarchenko et Makarchenko, 2015, Metriocnemus aprilis Makarchenko et Makarchenko, 2020, and Tvetenia vialis Makarchenko et Makarchenko, 2012. Of them L. omelkoi and M. aprilis are endemic to this stream, wile other species was found in perennial stream habitats. In water period the greatest richness values were observed in April (20 taxa recorded) and lowest in June (7 taxa). In the dry period (October), only 5 taxa were registered. According to biological characteristics, such chironomid species as H. majus, H. distinctus, Hydrobaenus sp. and Eukiefferiella gr. brehmi withstand the dry period with cocoons. The dominant species by abundance during period investigation were $H$. majus, $H$. distinctus, Orthocladius (Mesorthocladius) lamellatus Sæther, T. vialis, and Hydrobaenus sp.

Key words: Chironomidae, temporary stream, adaptation, cocoons, species riches, abundance, East Palaearctic. 
T. М. Тиунова, Е. А. Макарченко. Сообщество хирономид (Diptera: Chironomidae) временного ручья Южного Приморья (Дальний Восток России) // Дальневосточный энтомолог. 2020. N 414. С. 1-10.

Резюме. Изучена фауна хирономид временного ручья Южного Приморья в течение водного и безводного сезонов 2013 г. Всего в ходе исследования было выявлено 26 таксонов из подсемейств Diamesinae, Orthocladiinae, Chironominae и Tanypodinae. Для 5 видов (Lappodiamesa omelkoi Makarchenko et Makarchenko, 2013, Hydrobaenus distinctus Makarchenko et Makarchenko, 2006, H. majus Makarchenko et Makarchenko, 2015, Metriocnemus aprilis Makarchenko et Makarchenko, 2020 и Tvetenia vialis Makarchenko et Makarchenko, 2012) этот ручей является типовой местностью, причем L. omelkoi и M. aprilis известны только отсюда, а остальные обитают и в постоянных водотоках. В водный период наибольшее разнообразие хирономид наблюдалось в апреле (20 таксонов), а самое низкое в июне (7 таксонов). В безводный период (октябрь) было зарегистрировано пять таксонов, при этом важной биологической особенностью H. majus, H. distinctus, Hydrobaenus sp. и Eukiefferiella gr. brehmi является образование коконов. Доминирующими видами по численности в период исследований были Hydrobaenus sp., H. majus, H. distinctus, Orthocladius (Mesorthocladius) lamellatus Sæther и T. vialis.

\section{INTRODUCTION}

Insects of the family Chironomidae are distributed around the world and use a variety of habitats for larval development. The main habitats of freshwater species of chironomids are lakes, rivers, streams, springs, etc. Some of these habitats are temporary. In nature, there is a wide range of temporary, seasonal drying habitats for chironomids - these are rain pools, temporary pools and streams. Temporary habitats are often spatially predictable. These are temporary waters that re-occur each season in the same place for a long time (McLachlan, Ladle, 2001). Temporary streams can be classified as intermittent, with a seasonal cyclic pattern of dryness and flowing water (Williams, 1997). Temporal streams are habitats with a predictable annual dry phase of up to 8 months, usually during the second half of summer. These habitats function in response to cyclical flood and drought. Water volume in temporary streams depends on melting snow, rainfall, and groundwater discharge. Hydroperiod is a primary factor that determines the composition and structure of aquatic communities (Boix et al., 2001). Temporal streams support biological communities that different from communities in perennial stream habitats. Ecosystems in temporary streams typically support lower species richness, yet some studies show the importance of temporary waters for rare and endangered invertebrate species (Collinson et al., 1995; Standen, 1999; Della Bella et al., 2005). Organisms that occupy temporary waters are adapted to survival in temporary drought conditions. Some species occur exclusively in these ecosystems (Williams, 2006). They develop morphological adaptations and life cycles that allow survival in dry conditions (Frouz 
et al., 2003). Adaptation to the use of temporary habitats can be divided into two main groups. First, a very simple behavioral adaptation is the migration of larvae to wet places. The second is the structure of cocoons. Cocoons are built from the secretion of the salivary glands and are covered with particles of soil. The construction of cocoons is a common feature of the species of chironomids living in seasonal waters (Jones, 1974, 1975; Grodhaus, 1980).

To date, no Russian studies are available regarding the identification of species composition of chironomids, and their communities in temporary streams. This work is the first to show the unique species richness of chironomids in a temporary stream and to trace the dynamics of their community during the wet season.

\section{STUDY AREA}

The investigation was carried out in the temporary stream which flows along the road in Gornotaezhnoe village (Mountain-Taiga Station, Federal Scientific Center of the East Asia Terrestrial Biodiversity, Far East Branch of the Russian Academy of Sciences). During the wet season, the stream flows into Bolshoi Krivoi, a stream on the western slope of the Przhevalsky Mountains in the River Komarovka valley. The village of Gornotaezhnoe is located $25 \mathrm{~km}$ north of Ussuriysk City, Primorye Territory $\left(43^{\circ} 41^{\prime} 45^{\prime \prime} \mathrm{N}, 132^{\circ} 9^{\prime} 23^{\prime \prime} \mathrm{E}\right)$.

The small mountain river Bolshoi Krivoy Klyuch is $\sim 300 \mathrm{~m}$ wide. Slopes of hills approaching the valley display steepness of $5^{\circ}$ to $25^{\circ}$ and reach a height of $200 \mathrm{~m}$ above sea level. The territory of the Mountain-Taiga Station is part of the Amur-Ussuriisk climatic region of the temperate zone, where monsoons are most pronounced.

The meteorological regime in the winter months reflects the cold and dry northwestern continental winds. In summer months, cyclonic activity often brings moisture from the south. In June-September, up to $70 \%-75 \%$ of annual precipitation $(717 \mathrm{~mm}$ ) falls. The winter period lasts about five months (from early November to 1 April). Winters are not snowy; the average thickness of the snow cover is $30 \mathrm{~cm}$. Soil frost is deep $100-150 \mathrm{~cm}$. The minimum winter temperature is $-40.2^{\circ} \mathrm{C}$, and maximum summer temperature $+35.9^{\circ} \mathrm{C}$. The frost-free period lasts 169 days.

\section{MATERIALS AND METHODS}

The length of temporary stream is approximately $200 \mathrm{~m}$ (Fig. 1). The bottom of the stream is swampy much silt and residue of half-rotten plants. Depth ranged from five to $25 \mathrm{~cm}$ (Tiunova, 2019). Samples were taken in 2013 from April to June (15 and 28 April; 6, 16 and 27 May and 7 June). One sample was taken on 5 October, when water absent. Samples were collected by using the GR-91 rod bottom scoop (coverage area $0.007 \mathrm{~m}^{2}$ ) (Fig. 2). A total of 14 samples were obtained. Material was preserved in $4 \%$ formalin and sorted out and species identified at the laboratory.

Water temperature $\left({ }^{\circ} \mathrm{C}\right), \mathrm{pH}$, and electrical conductivity were measured in situ, while chironomids were being sampled using a portable YSI Multi-Plus professional equipment (Table 1). 
Table 1. Characteristics of the temporal stream studied in 2013

\begin{tabular}{|l|c|c|c|}
\hline Data & Temperature, ${ }^{\circ} \mathrm{C}$ & $\mathrm{pH}$ & $\mathrm{EC}$ \\
\hline 15 April & 0.3 & $7.0-7.8$ & $95-122$ \\
\hline 28 April & 2.1 & $7.2-7.8$ & $71-72$ \\
\hline 6 May & 7.1 & $7.5-8.2$ & $70-106$ \\
\hline 16 May & 11.0 & $6.7-6.8$ & $62-67$ \\
\hline 27 May & 11.6 & $6.6-6.9$ & $58-63$ \\
\hline 7 June & 12.4 & $7.0-7.8$ & - \\
\hline 5 October & - & - & - \\
\hline
\end{tabular}

To characterize the structure of the community, we used the classification of Cheltsov-Bebutov modified by Levanidov (1977), according to which dominants make up $15 \%$ or more of the total density, subdominants - from 5.0 to $14.9 \%$, minor species - from 1.0 to $4.9 \%$, tertiary - less than $1.0 \%$.

Photographs were taken with the stereomicroscope Olympus SZX16 and digital camera Olympus DP74, and stacked using Helicon Focus software.
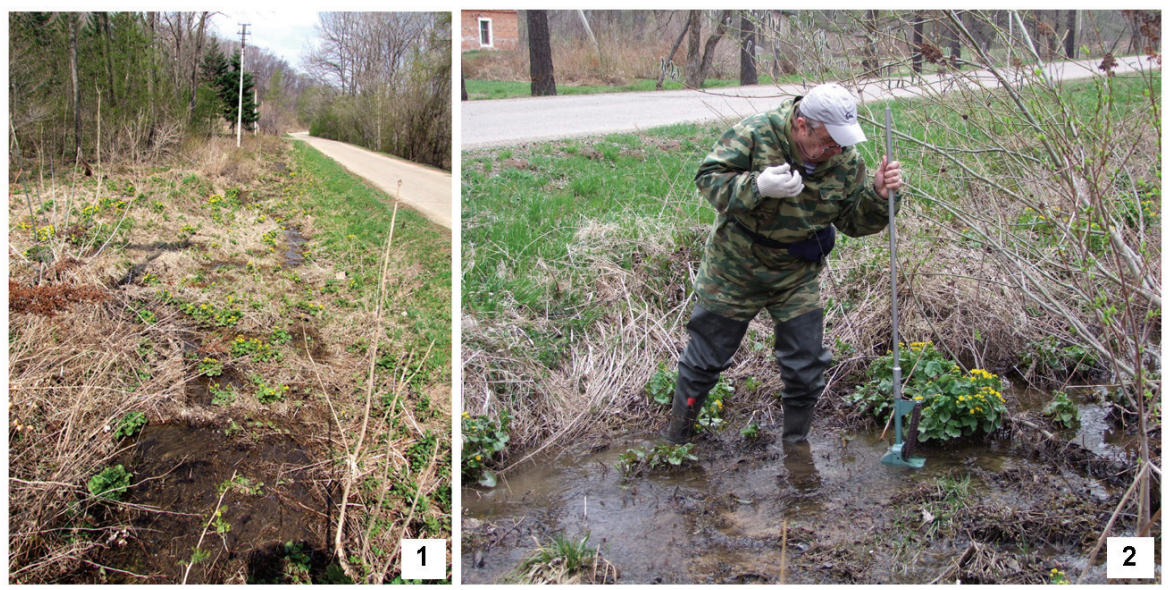

Figs 1, 2. Gornotaezhnoe village (Mountain-Taiga Station). 1 - temporary stream flowing along the road; 2 - sampling using the GR-91 rod bottom scoop.

\section{RESULTS AND DISCUSSION}

A total of 25 species of chironomids were recorded from the temporal stream during the study period (Table 2). The most of the species belong to the subfamily Orthocladiinae (20 species). Among other subfamilies Diamesinae and Chironominae were presented by two species. Regarding Tanypodinae has not been identified to the lowest possible taxonomic level. 
Table 2. List of taxa and abundance of chironomids (ind. $/ \mathrm{m}^{2} / \%$ ) in temporal stream in 2013

\begin{tabular}{|c|c|c|c|c|c|c|c|}
\hline \multirow{2}{*}{ Taxa } & \multicolumn{7}{|c|}{ Time of sampling } \\
\hline & $\begin{array}{c}15 \\
\text { April }\end{array}$ & $\begin{array}{c}28 \\
\text { April }\end{array}$ & $\begin{array}{c}6 \\
\text { May }\end{array}$ & $\begin{array}{c}16 \\
\text { May }\end{array}$ & $\begin{array}{c}27 \\
\text { May }\end{array}$ & $\begin{array}{c}7 \\
\text { June }\end{array}$ & \begin{tabular}{|c|}
5 \\
October \\
\end{tabular} \\
\hline \multicolumn{8}{|l|}{ Subfamily Diamesinae } \\
\hline $\begin{array}{l}\text { Lappodiamesa omelkoi } \\
\text { Makarchenko et } \\
\text { Makarchenko, } 2013\end{array}$ & $\begin{array}{c}167 / \\
1.0\end{array}$ & $\begin{array}{c}214 / \\
0.7\end{array}$ & $\begin{array}{l}71 / \\
0.4\end{array}$ & - & - & - & - \\
\hline $\begin{array}{l}\text { Pagastia orientalis } \\
\text { Chernovskij, } 1949\end{array}$ & - & - & - & - & $\begin{array}{c}143 / \\
9.5\end{array}$ & $\begin{array}{l}71 / \\
1.0\end{array}$ & - \\
\hline \multicolumn{8}{|l|}{ Subfamily Orthocladiinae } \\
\hline $\begin{array}{l}\text { Diplocladius cultriger } \\
\text { Kieffer, } 1908\end{array}$ & $238 / 1.4$ & $357 / 1.2$ & + & - & - & - & - \\
\hline Corynoneura sp. & $95 / 0.6$ & $107 / 0.4$ & $71 / 0.4$ & - & - & - & - \\
\hline Hydrobaenus sp. & $\begin{array}{c}1024 / \\
6.0\end{array}$ & $\begin{array}{c}6000 / \\
20.7 \\
\end{array}$ & $\begin{array}{c}821 / \\
5.0\end{array}$ & $\begin{array}{l}71 / \\
2.0\end{array}$ & $\begin{array}{l}357 / \\
23.8\end{array}$ & $\begin{array}{c}4035 / \\
55.1\end{array}$ & $\begin{array}{c}15714 / \\
39.5\end{array}$ \\
\hline $\begin{array}{l}\text { H. distinctus Makarchenko } \\
\text { et Makarchenko, } 2006\end{array}$ & $\begin{array}{c}3214 / \\
18.8\end{array}$ & $\begin{array}{l}4357 / \\
15.0\end{array}$ & $\begin{array}{c}5785 / \\
35.2\end{array}$ & $\begin{array}{l}928 / \\
25.7\end{array}$ & + & $\begin{array}{c}143 / \\
2.0\end{array}$ & $\begin{array}{l}5704 / \\
22.5\end{array}$ \\
\hline $\begin{array}{l}\text { H. majus Makarchenko et } \\
\text { Makarchenko, } 2015\end{array}$ & $\begin{array}{l}3190 / \\
18.7\end{array}$ & $\begin{array}{c}5499 / \\
19.0\end{array}$ & + & + & $\begin{array}{l}607 / \\
40.5\end{array}$ & $\begin{array}{c}1178 / \\
16.1\end{array}$ & $\begin{array}{c}9428 / \\
37.2\end{array}$ \\
\hline Eukiefferiella gr. brehmi & - & - & - & - & $214 / 14.3$ & $1535 / 21.0$ & $71 / 0.3$ \\
\hline Limnophyes sp. & $1666 / 9.7$ & $750 / 2.6$ & $392 / 2.4$ & - & - & - & - \\
\hline Metriocnemus sp.1 & $\begin{array}{c}1547 / \\
9.1\end{array}$ & $\begin{array}{c}1393 / \\
4.8\end{array}$ & $\begin{array}{c}1214 / \\
7.4\end{array}$ & $\begin{array}{c}143 / \\
4.0\end{array}$ & - & - & - \\
\hline Metriocnemus sp. 2 & $48 / 0.3$ & - & $71 / 0.4$ & - & - & - & - \\
\hline $\begin{array}{l}\text { M. aprilis Makarchenko et } \\
\text { Makarchenko, } 2020\end{array}$ & - & + & - & - & - & - & - \\
\hline Orthocladius sp. & $71 / 0.4$ & - & - & - & $178 / 11.9$ & $286 / 3.9$ & - \\
\hline $\begin{array}{l}\text { O. (Euorthocladius) } \\
\text { abiskoensis Thienemann et } \\
\text { Krueger, } 1937\end{array}$ & - & - & - & $\begin{array}{c}143 / \\
4.0\end{array}$ & - & - & - \\
\hline $\begin{array}{l}\text { O. (Mesorthocladius) } \\
\text { lamellatus Sæther, } 2005\end{array}$ & - & $\begin{array}{c}1214 / \\
4.2\end{array}$ & $\begin{array}{c}4143 / \\
25.2\end{array}$ & $\begin{array}{c}2143 / \\
59.4\end{array}$ & - & - & - \\
\hline $\begin{array}{l}\text { O. ? lapponicus } \\
\text { Goetghebuer, } 1940\end{array}$ & - & $321 / 1.1$ & - & - & - & - & - \\
\hline Parachaetocladius sp. & - & - & $143 / 0.9$ & - & - & - & - \\
\hline ?Pseudorthocladius sp. & $48 / 0.3$ & - & - & - & - & - & - \\
\hline Smittia $\mathrm{sp}$. & - & $71 / 0.2$ & - & - & - & - & - \\
\hline Pseudosmittia sp. & - & $71 / 0.2$ & - & - & - & - & - \\
\hline Rheocricotopus sp. & $190 / 1.1$ & $107 / 0.4$ & - & - & - & - & - \\
\hline $\begin{array}{l}\text { Tvetenia vialis Makarchenko } \\
\text { et Makarchenko, } 2012\end{array}$ & $\begin{array}{c}4404 / \\
25.8\end{array}$ & $\begin{array}{c}8000 / \\
27.6\end{array}$ & $\begin{array}{l}3571 / \\
21.7 \\
\end{array}$ & $\begin{array}{c}178 / \\
4.9\end{array}$ & - & - & - \\
\hline \multicolumn{8}{|l|}{ Subfamily Chironominae } \\
\hline Polypedilum gr. convictum & $47 / 0.3$ & - & - & - & - & - & - \\
\hline Polypedilum sp. & - & - & + & - & - & $71 / 1.0$ & $143 / 0.6$ \\
\hline
\end{tabular}


Table 2. Continue

\begin{tabular}{|c|c|c|c|c|c|c|c|}
\hline \multirow{2}{*}{ Taxa } & \multicolumn{7}{|c|}{ Time of sampling } \\
\cline { 2 - 8 } & $\begin{array}{c}15 \\
\text { April }\end{array}$ & $\begin{array}{c}28 \\
\text { April }\end{array}$ & $\begin{array}{c}6 \\
\text { May }\end{array}$ & $\begin{array}{c}16 \\
\text { May }\end{array}$ & $\begin{array}{c}27 \\
\text { May }\end{array}$ & $\begin{array}{c}7 \\
\text { June }\end{array}$ & $\begin{array}{c}5 \\
\text { October }\end{array}$ \\
\hline $\begin{array}{c}\text { Subfamily Tanypodinae } \\
\text { (indeterminate) }\end{array}$ & $1143 / 6.7$ & $500 / 1.7$ & $143 / 0.9$ & + & - & - & - \\
\hline Total number of taxa: & 15 & 16 & 14 & 8 & 6 & 7 & 5 \\
\hline Total abundance: & 17092 & 28961 & 16425 & 3606 & 1499 & 7319 & 25356 \\
\hline
\end{tabular}

Note: +- the species was noted in quality samples.

In water period the greatest richness values were observed in April (19 taxa recorded) and lowest in end of May (6 taxa). In the dry period, only 5 species were registered.

Recently, five species of chironomids have been described as new for science from a temporary stream: Lappodiamesa omelkoi Makarchenko et Makarchenko, 2013, Hydrobaenus distinctus Makarchenko et Makarchenko, 2006, H. majus Makarchenko et Makarchenko, 2015, Tvetenia vialis Makarchenko et Makarchenko, 2012 and Metriocnemus aprilis Makarchenko et Makarchenko, 2020.

The results of the study show that the diversity and abundance of separate chironomid species during spring - summer period depend upon of their life cycles. The dominant species by abundance during period investigation were Hydrobaenus sp., H. majus, H. distinctus, Orthocladius (Mesorthocladius) lamellatus Sæther, 2005, and T. vialis.

Lappodiamesa omelkoi is known from the type locality only (Makarchenko \& Makarchenko, 2013). Pupae and larvae were collected in detritus with sand sampled from stream with depth $5-15 \mathrm{~cm}$. Larvae recorded in samples on April 15 immediately after the disappearance of ice in the stream. The first adult collected on April 28 and last larvae were recorded in samples on May 6. Thus, by mid-May, $L$. omelkoi leaves the watercourse.

Hydrobaenus majus was collected and described from a temporal stream. Second place where this species was collected is Khabarovsk Territory, Bolshekhehtsyrsky Nature Reserve, Golovina Stream, Ussuri River basin (Makarchenko et al., 2015; Yavorskaya et al., 2017).

The large numbers of cocoons were recorded in samples during April. The first adults, pupae and larvae $H$. majus were noted in quality samples on May 6. Subsequently, all stages of development were recorded in samples until May 16. In quantitative samples for May 27, young larvae and new cocoons with larvae of I-II instars were observed (Figs 3-5). By June 7, only a few individuals and numerous cocoons $\left(1178\right.$ ind. $/ \mathrm{m}^{2}$ ) were recorded in the stream again (Table 2). In the dry period (October 5), the number of cocoons reached 9428 ind. $/ \mathrm{m}^{2}(37.2 \%)$. Thus, the emergence of larvae of I-II instars from cocoons occurs, apparently, in April, immediately after the ice melts. The first adults were recorded in early May. Hatching juveniles go to diapauses in early June not long before the start of the dry period. 
Hydrobaenus distinctus - third species of the genus Hydrobaenus which inhabited in a temporary stream. In addition to Primorye, this species was noted in Michurinsk Lake, (Makarchenko \& Makarchenko, 2014) and Bolshekhehtsyrsky Nature Reserve, Khabarovsk Territory (Yavorskaya et al., 2017). Unlike previous species, $H$. distinctus was noted in the temporal stream during the entire period of research.

Numerous larvae $H$. distinctus were recorded in samples April 15. The first mature pupae and imagines were collected in quality samples from 6 to 27 May. The abundance of larvae increased until May 6 and sharply decreased on May 16. In the samples May 27, larvae were absent, and in the samples June 7 cocoons were registered (Fig. 3) the number of which on October 5 (dry season) increased to 5704 ind. $/ \mathrm{m}^{2}(22.5 \%)$. Thus, as with H. majus, the main growth and development falls on April - May. Hatching larvae that reached II instar at the beginning of June go into diapause until the next water season.

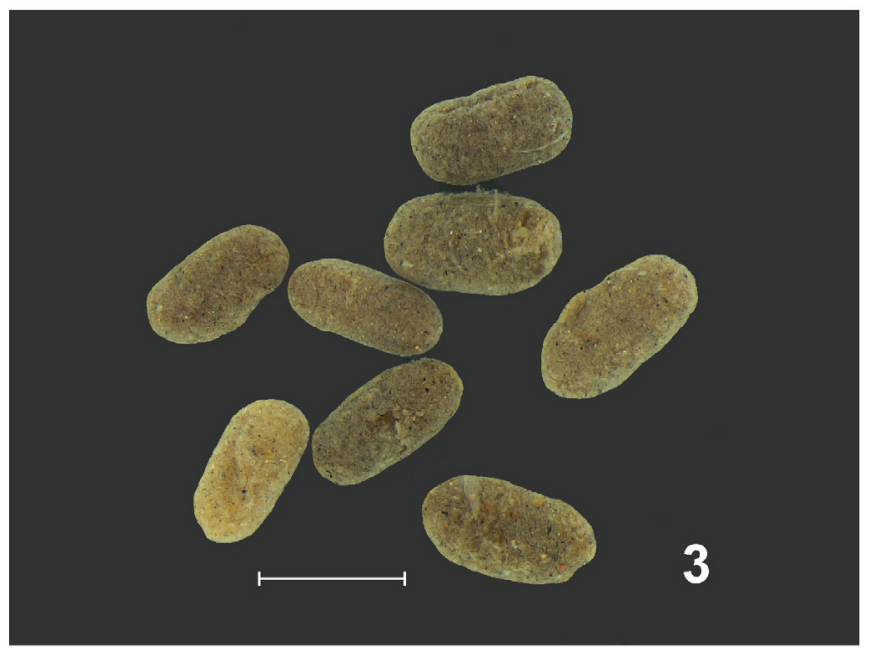

Fig. 3. Cocoons of Hydrobaenus distinctus and H. majus. Scale bar: $1 \mathrm{~mm}$.

Tvetenia vialis was collected and described from temporal stream (Makarchenko \& Makarchenko, 2012). In 2017 this species was recorded in Sosninskiy Stream Bolshekhehtsyrsky Nature Reserve, Khabarovsk Territory (Yavorskaya et al., 2017).

The abundance of larvae recorded in samples on April 15 was 4404 ind. $/ \mathrm{m}^{2}$ or $25.8 \%$ of the chironomid community. On April 28, the maximum density was recorded ( 8000 ind.$/ \mathrm{m}^{2}$ or $27.6 \%$ ). By May 6 , the abundance of $T$. vialis larvae had more than halved, and first mature pupae were recorded. By May 16 only a few individuals were recorded in the stream (Table 2).

Thus, the main growth and development of $T$. vialis in a temporary stream occurs during April and May. 
Orthocladius (M.) lamellatus - single larvae were recorded in benthos on April 15, and their maximum was recorded in early May (Table 2). On May 16, the density of O. (M.) lamellatus halved and amounted to 2143 ind. $/ \mathrm{m}^{2}$ or $59.4 \%$ of chironomids community. Moreover, a large proportion (65\%) was pupae. May 27 and June 7 , hatching juveniles identified by us as Orthocladius sp. It is likely that this juvenile belongs to $O$. (M.) lamellatus.

Thus, probably $O$. (M.) lamellatus hibernates in the young larva stage and appears in benthos immediately after ice melts. The main growth and development is in April and early May. By the end of May, the view flies completely.

Metriocnemus aprilis is known from the type locality only (Makarchenko \& Makarchenko, 2020).

During the study period, Pagastia orientalis, Orthocladius (E.) abiskoensis, $O$. ? lapponicus, Parachaetocladius sp., Smittia sp., Pseudosmittia sp. and other were singly noted in the community.

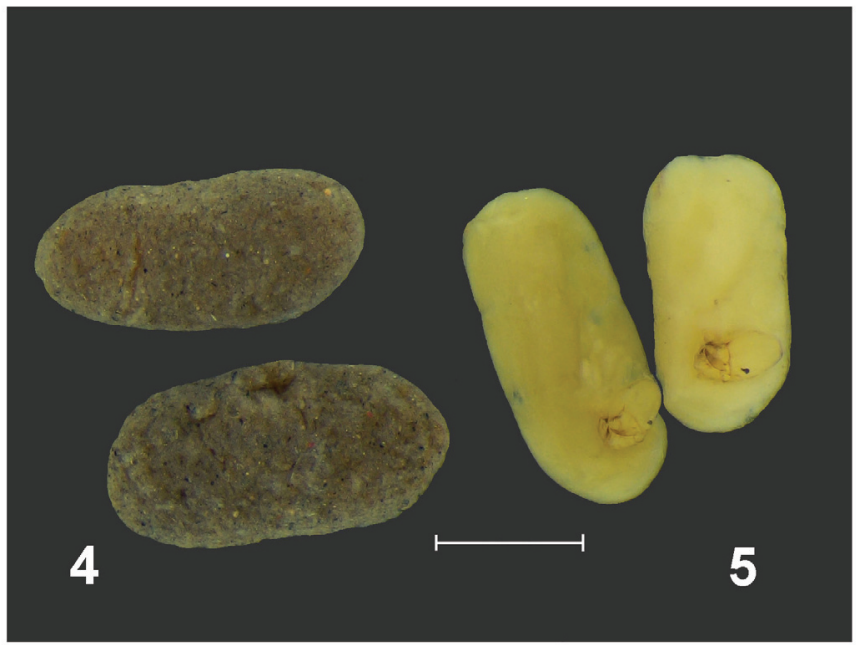

Figs 4-5. Hydrobaenus majus. 4 - cocoons; 5 - larvae removed from cocoons. Scale bar: $0.5 \mathrm{~mm}$.

\section{CONCLUSION}

Despite their ephemeral nature and small size, temporary streams have a great importance for biodiversity maintenance in particular as regards some rare invertebrate species (Williams, 1997). According to Boix et al., 2001, the faunal composition of temporary aquatic ecosystems includes species associated with permanent environments and species that exclusively inhabit these environments due to their biological adaptations. Similar results were observed in our study. In the studied stream chironomids L. omelkoi, and M. aprilis are found only in temporary water 
bodies. All of these species are known only from the typical habitat. A number of other species, such as $H$. majus and $H$. distinctus, can inhabit both temporary streams and permanent streams. The studied chironomids community of the temporary stream turned out to be adapted to a relatively short (2.5-3 months) water period. According to biological characteristics, such chironomid species as $H$. majus, H. distinctus, Hydrobaenus sp. and Eukiefferiella gr. brehmi withstand the dry period with cocoons.

The results of the study show that the diversity and abundance of separate chironomid species during spring - summer period depend upon of their life cycles. In water period maximum species was recorded in April and minimum in end of May. According to chironomids fauna, the dominant species by abundance during period investigation were $H$. majus, $H$. distinctus $O$. (M.) lamellatus, $T$. vialis and Hydrobaenus sp.

\section{ACKNOWLEDGMENTS}

We much grateful to Marina A. Makarchenko for chironomid identification of Orthocladiinae subfamily and to Valentina A. Teslenko for help in preparing of photographs from microscope.

\section{REFERENCES}

Boix, D., Sala, J. \& Moreno-Amichi, R. 2001. The faunal composition of Espolla pond (NE Iberian Peninsula): the neglected biodiversity of temporary waters. Wetlands, 21: 577592.

Collinson, N.H., Biggs, J., Corfield, A., Hodson, M.J., Walker, D., Whitfield. M. \& Williams, P.J. 1995. Temporary and permanent ponds: an assessment of the effects of drying out on the conservation value of aquatic macroinvertebrate communities. Biological Conservation, 74: 125-133.

Della Bella, V., Bazzanti, M. \& Chiarotti, F. 2005. Macroinvertebrate diversity and conservation status of Mediterranean ponds in Italy: water permanence and mesohabitat influence. Aquatic Conservation: Marine and Freshwater Ecosystems, 15: 583-600.

Frouz , J. \& Matĕna, J. \& Ali, A. 2003. Survival strategies of chironomids (Diptera: Chironomidae) living in temporary habitats: a review. European Journal of Entomology, 100: 459-465.

Grodhaus, G. 1980. Aestivating Chironomid larvae associated with vernal pools. P. 315-322. In: Murray D.A.(Ed.). Chironomidae Ecology, Systematic, Cytology and Physiology. Pergamon Press, Oxford \& New York.

Jones R.E. 1974. The effect of size selective predation on the environmental variation in the distribution and abundance of a chironomid, Paraborniella tonniri Freeman. Australian Journal Zoology, 22: 71-89.

Jones, R.E. 1975. Dehydratation in an Australian rockpool chironomid larva Paraborniella tonniri. Journal of Entomology, 49: 111-119.

Levanidov, V.Ya. 1977. Biomass and structure of benthic biocenoses in the Kedrovaya River. P. 126-159. In: Freshwater Fauna of the Kedrovaya Pad' Nature Reserve. Vladivostok. [In Russian] 
Makarchenko, E.A. \& Makarchenko, M.A. 2012. Review of Tvetenia Kieffer (Diptera, Chironomidae, Orthocladiinae) from the Russian Far East and bordering territories. Euroasian Entomological Journal, 11: 137-152. [In Russian]

Makarchenko, E.A. \& Makarchenko, M.A. 2013. A new species of Lappodiamesa SerraTosio (Diptera: Chironomidae: Diamesinae) from the Russian Far East, with a key to known species of the genus. Zootaxa, 3709: 591-596. DOI: https://doi.org/10.11646/ zootaxa.3709.6.8

Makarchenko, E.A. \& Makarchenko, M.A. 2014. On taxonomy of Hydrobaenus Fries, 1830 (Diptera: Chironomidae: Orthocladiinae) from the Russian Far East, with a key to species. Zootaxa, 3760: 429-438. DOI: http://dx.doi.org/10.11646/zootaxa.3760.3.9

Makarchenko, E.A. \& Makarchenko, M.A. 2020. New data on chironomid taxonomy of the Orthocladiinae subfamily (Diptera, Chironomidae) from the Russian Far East and bordering territories. Euroasian Entomological Journal, 19: 38-46. [In Russian] DOI: https://doi.org/10.15298/euroasentj.19.1.06

Makarchenko, E.A., Makarchenko, M.A. \& Semenchenko, A.A. 2015. Morphological description and DNA barcoding of Hydrobaenus majus sp. nov. (Diptera: Chironomidae: Orthocladiinae) from the Russian Far East. Zootaxa, 4000: 287-293. DOI: https://doi.org/ 10.11646/zootaxa.4000.2.7

McLachlan, A. \& Ladle, R. 2001. Life in the puddle: behavioral and life-cycle adaptations in the Diptera of tropical rain pools. Biological Reviews, 76:377-388.

Standen, V. 1999. Quantifying macroinvertebrate taxon richness and abundance in open and forested pool complexes in the Sutherland Flows. Aquatic Conservation: Marine and Freshwater Ecosystems, 9: 209-217.

Tiunova, T.M. 2019. Life cycle and growth of Metreletus omelkoi Tiunova, 2010 (Ephemeroptera: Ameletidae) in a temporary stream in Primorskii krai, Russia. Far Eastern Entomologist, 388: 23-32. DOI: https://doi.org/10.25221/fee.388.3

Williams, D.D. 1997.Temporary ponds and their invertebrate communities. Aquatic Conservation: Marine and Freshwater Ecosystems, 7: 105-117.

Williams, D.D. 2006. The Biology of Temporary Waters. Oxford University Press, Oxford. $337 \mathrm{p}$.

Yavorskaya, N.M., Makarchenko, M.A., Orel, O.V. \& Makarchenko, E.A. 2017. The chironomid fauna (Diptera, Chironomidae) of the Bolshekhekhtsirsky Nature Reserve (Khabarovskii Krai, Russia). Euroasian Entomological Journal, 16: 180-191. [In Russian] 